\title{
Limited wind-driven dispersal of intertidal mussel larvae: in situ evidence from the plankton and the spread of the invasive species Mytilus galloprovincialis in South Africa
}

\author{
C. D. McQuaid*, T. E. Phillips \\ Department of Zoology \& Entomology, Rhodes University, Grahamstown 6140, South Africa
}

\begin{abstract}
Dispersal of intertidal mussel propagules was examined by sampling larvae (0.2 to $0.8 \mathrm{~mm}$ ) of Perna perna in shallow $(10$ to $20 \mathrm{~m}$ ) inshore waters on the south coast of South Africa. Mussels were randomly distributed through the water column with no signs of diel vertical migration. Horizontal distribution was sampled on fine scale grids of plankton stations on 5 occasions. Lines of stations ran offshore and were $300 \mathrm{~m}$ apart. Within each line, stations were $10 \mathrm{~m}$ apart. On each occasion grids were sampled 3 to 4 times in rapid succession so that each station was sampled at intervals of about $1 \mathrm{~h}$. Distribution was patchy and denser clouds of larvae moved in the same direction and at the same speeds as surface currents. Displacement of passive particles moving with wind-driven currents was estimated from wind data. Over periods of 1 mo estimated total displacement was 118 to $220 \mathrm{~km}$ depending on month and year. However, because of frequent changes in wind direction, net displacement for any month was 54 to $164 \mathrm{~km}$ to the northeast. These estimates were compared with the rate of spread over $4 \mathrm{yr}$ of an invasive intertidal mussel (Mytilus galloprovincialis) dispersing initially from a single-point source. Spread was estimated as the furthest occurrence of M. galloprovincialis from the parent population. After $4 \mathrm{yr}, 90 \%$ of individuals sampled were $<5 \mathrm{~km}$ from the original population. Yearly increase in range between 1988 (introduction to the area) and 1992 was strongly directional: 55 to $97 \mathrm{~km}$ to the northeast and 12 to $29 \mathrm{~km}$ to the southwest. The good match with estimates from wind data implies that mussel larvae in this region are dispersed like passive particles and that dispersal direction and ranges can be predicted from hydrographic data. The results strongly suggest that maximum effective dispersal of mussel larvae in this area is relatively limited $(<100 \mathrm{~km})$, with the great majority of successful recruits appearing within $<5 \mathrm{~km}$ of the parent population.
\end{abstract}

KEY WORDS: Intertidal $\cdot$ Invasive species $\cdot$ Larval dispersal $\cdot$ Mussels $\cdot$ Mytilus $\cdot$ Perna

\section{INTRODUCTION}

For benthic species, the scales of dispersal of planktonic larvae are important in evolution, because they influence gene flow among populations (Jablonski \& Lutz 1983, Jablonski 1986, Strathmann 1990, but see Hedgecock 1986), and in ecology through their link to larval supply. It is often assumed that populations with

*E-mail: zocm@hippo.ru.ac.za long-lived planktonic larvae are open, meaning that recruits are supplied from other populations. 'Local' recruitment is uncoupled from local reproduction by a dispersive larval phase (Caley et al. 1996, Palmer et al. 1996). A critical point is the issue of spatial scales and what constitutes a 'local' population. The answer is clearly linked to the biology of the organism, as scales of propagule dispersal differ among taxa.

At one extreme teleplanic larvae can disperse on oceanic scales (Scheltema 1966, 1968, 1971，1986a, Scheltema \& Williams 1983, Perron \& Kohn 1985), 
while at the other extreme, algal spores and shortlived lecithotrophic larvae may disperse on scales of only 10 to 100 s of metres (Olson \& McPherson 1987, Stoner 1990, Booth \& Brosnan 1995, Todd et al. 1998). Between these extremes are planktotrophic larvae which are in the water column for weeks or possibly months. These are believed to disperse over large scales so that populations of marine benthic species are demographically open (Roughgarden et al. 1985, Possingham \& Roughgarden 1990, Farrell et al. 1991, Gaines \& Bertness 1992, Alexander \& Roughgarden 1996, Caley et al. 1996). However, direct evidence on the scale of dispersal of such species is rare; perhaps the best evidence comes from linking larval distribution with the movement of oceanographic features (e.g. Roughgarden et al. 1988).

Larvae need not behave as passive particles, and a number of studies demonstrate the importance of larval behaviour in the control of their position in the water column at small scales. This can be used to exploit consistent counter-currents or layering of the water column so that some degree of control of dispersal can be achieved (e.g. Carricker 1951, Wood \& Hargis 1971, Laprise \& Dodson 1989, Jacobsen et al. 1990, Hovel \& Morgan 1997). Nevertheless, larvae are presumably incapable of moving between water masses except by sinking or floating, so that factors which delimit water masses such as fronts and factors which control the movement of water masses will be important. As a result, physical factors controlling the advection and trapping of larvae have a powerful effect on their dispersal (e.g. de Wolf 1973, Shanks 1983, 1986, Heath et al. 1987, Roughgarden et al. 1988, Sammarco \& Andrews 1989, Hill 1990, Willis \& Oliver 1990, Hinckley et al. 1991, Pineda 1991, Pedrotti \& Fenaux 1992, see also Table 2 in Booth \& Brosnan 1995).

We wished to estimate the scale of dispersal of the larvae of intertidal mussels on the south coast of South Africa. The difficulty in studying larval dispersal is that one knows where survivors appear, but not where they have come from. One way of resolving this is to study larvae dispersing from a point source. We examined whether the larvae of an indigenous, abundant mussel (Perna perna) are able to use behaviour to exploit counter-currents etc. to influence their horizontal movement. Subsequently we examined the horizontal movement of mussel larvae in the inshore water column and used wind data to predict dispersal ranges for larvae acting as passive particles dispersed by wind-driven surface currents. Finally, calculated dispersal ranges were compared with changes in the distributional range of an invasive mussel (Mytilus galloprovincialis) over $4 \mathrm{yr}$ from its introduction to a single locality in the region.

\section{METHODS AND MATERIALS}

This study has 3 components: (1) distribution of the larvae of Perna perna in inshore waters, (2) estimation of dispersal ranges of passive particles, (3) comparison of these estimates with range extension of Mytilus galloprovincialis.

Larval distribution. Because of the possibilty of larvae using behaviour to influence their position, both vertical and horizontal distribution were examined. Plankton sampling was carried out near Kenton on the south coast of South Africa ( $\left.33^{\circ} 41^{\prime} \mathrm{S}, 26^{\circ} 40^{\prime} \mathrm{E}\right)$, using a $0.250 \mathrm{~mm}$ mesh plankton net $30 \mathrm{~cm}$ in diameter with a cod end with a filtering mesh of $0.180 \mathrm{~mm}$. The net was used for vertical hauls and raised at approximately $0.33 \mathrm{~m} \mathrm{~s}^{-1}$. Water depth was approximately $10 \mathrm{~m}$ unless otherwise stated.

Vertical stratification: Vertical stratification of larvae was examined by sampling over discrete depth intervals. On 24 and 28 September 1990, separate $1 \mathrm{~m}$ and $10 \mathrm{~m}$ vertical hauls were performed at each station on a horizontal grid (see below). The abundance of larvae in $1 \mathrm{~m}$ and $10 \mathrm{~m}$ hauls was compared using a Mann-Whitney $U$-test (Zar 1984). On 18 and 19 March 1991 vertical distribution was examined at 1 station by taking vertical hauls over different depth intervals. The first ran from $1 \mathrm{~m}$ to the surface, the second from $2 \mathrm{~m}$ to the surface etc., down to the bottom at $10 \mathrm{~m}$. Each depth interval was replicated 2 or 3 times and the data pooled. The number of larvae in samples was correlated with the depth of sampling.

The possibility of vertical migration of larvae was examined in October 1991 at Fountain Rocks, a shallow reef $150 \mathrm{~m}$ offshore and approximately $30 \mathrm{~km}$ east of Kenton. Conditions were too dangerous to allow continuous sampling. Instead, vertical larval distribution was examined at dawn (05:30-07:10 h), during the day $(09: 36-11: 00 \mathrm{~h} ; 12: 52-13: 45 \mathrm{~h})$ and at dusk (16:50-18:30 h) between 16 and 18 October 1991. Sampling involved vertical plankton net hauls (3 replicates for each sample) over discrete depth intervals of 1 to $2 \mathrm{~m}$ from the surface to the bottom $(10 \mathrm{~m})$. The volume of water filtered was determined from the depth of the haul and the diameter of the net. A Kolmogorov-Smirnov test (Zar 1984) was used to compare the observed concentration of larvae at discrete depth intervals with those expected if larvae were uniformly distributed.

Horizontal dispersal on sampling grids: Small scale, short term changes in the horizontal distribution and abundance of larvae were examined on 5 occasions on sampling grids immediately offshore of the surf zone on 24 and 28 September 1990 and 18 and 19 March 1991. Three sampling grids were used to represent the main local inshore environments. Grid 1 was opposite 
a rocky platform populated by mussels. Grid 2 was opposite a sandy beach. Both grids were approximately $120 \mathrm{~m}$ offshore in $10 \mathrm{~m}$ of water. Grid 3 was further offshore from grid 1, in approximately $20 \mathrm{~m}$ of water, $400 \mathrm{~m}$ from the shoreline.

Each grid included 4 lines of stations running offshore at intervals of $10 \mathrm{~m}$. Grid 1 had five stations per line, grids 2 and 3 had four per line. The lines were $300 \mathrm{~m}$ apart (Fig. 1). At each station vertical plankton hauls were made, bottom to surface. Stations were sampled in numerical order, beginning inshore and ending offshore (e.g. grid 1 on Fig. 1). Sampling an entire grid took 1 to $2 \mathrm{~h}$, depending on weather, after which stations were sampled again in the same order. In this way stations were sampled repeatedly at short time intervals. The number of repeats was limited by weather conditions. Four repeats were carried out on 24 September, 3 on each of the other days. Larval abundance at each station was plotted for each sampling session using the computer software SURFER which fitted contours to illustrate larval density within grids. On each of the 5 sampling occasions, current speed and direction were recorded with a current meter either once or twice at $1 \mathrm{~m}$ depth intervals to the bottom.

Estimation of dispersal range. The rate and direction of movement of passively dispersed larvae were assumed to be the same as those of prevailing currents. Total and net distance and direction of dispersal in 1 mo were estimated from wind data using a model developed by Roberts (1989) for the nearshore zone of Algoa Bay. This was done using data on total duration and mean velocity of winds for each month between March 1989 and June 1991. Hourly data on wind speed and direction for the nearest weather station (approx. $100 \mathrm{~km}$ away) were obtained from Port Elizabeth Airport. Frequency was calculated as hours per month and a single mean velocity for each wind for each month was calculated from hourly wind data. Currents flow parallel to the coast under the 4 predominant wind directions (SW, SE, NW, NE). Dispersal distance was calculated as mean current speed, based on Roberts' model, multiplied by the duration of the wind blowing from each direction, or the residual velocity during calms. Total dispersal was the sum of movement in each direction. Net dispersal was the difference between northeastward movement during SW, SE and NW winds and calm periods, and the distance moved southwestwards during NE winds.

Rate of spread of an invasive species. The intertidal mussel Mytilus galloprovincialis was introduced to the region (Port Elizabeth harbour) as a single population for aquaculture in 1988. Rocky outcrops east and west of Port Elizabeth harbour were examined for M. gallo-

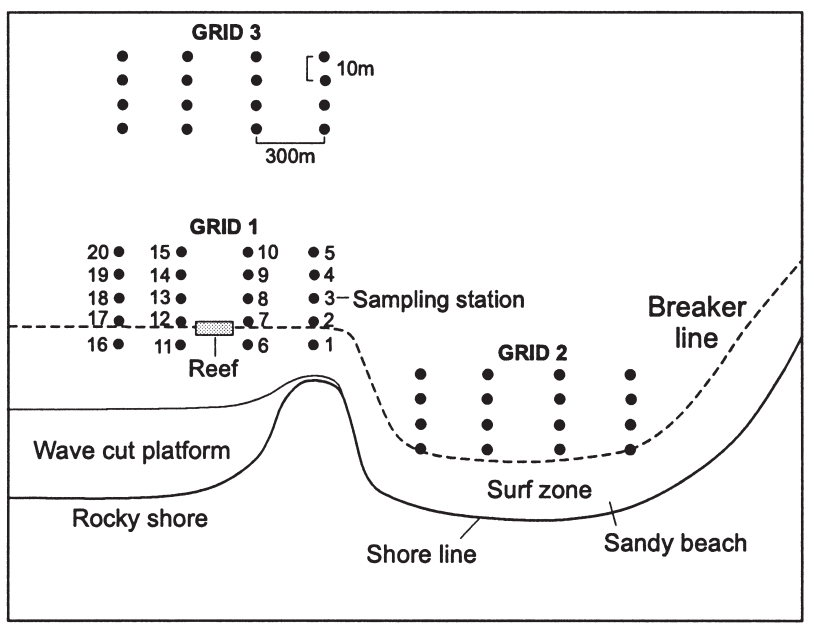

Fig. 1. Stylised map of Kenton showing position of sampling grids and arrangement of stations. Grid 1 sampled 24/9/90, 28/9/90 and 18/3/91 am. Grid 2 sampled 18/3/91 pm. Grid 3 sampled 19/3/91

provincialis once a year from 1989 to 1992. Surveys were extended so that each included several sites beyond the furthermost recorded occurrence of M. galloprovincialis. After a visual search for M. galloprovincialis, 3 quadrats of $12.5 \times 25 \mathrm{~cm}$ were placed randomly in each mussel habitat present and all mussels scraped from the rocks. Samples at each rock outcrop were repeated at $30 \mathrm{~m}$ intervals over the length of the outcrop.

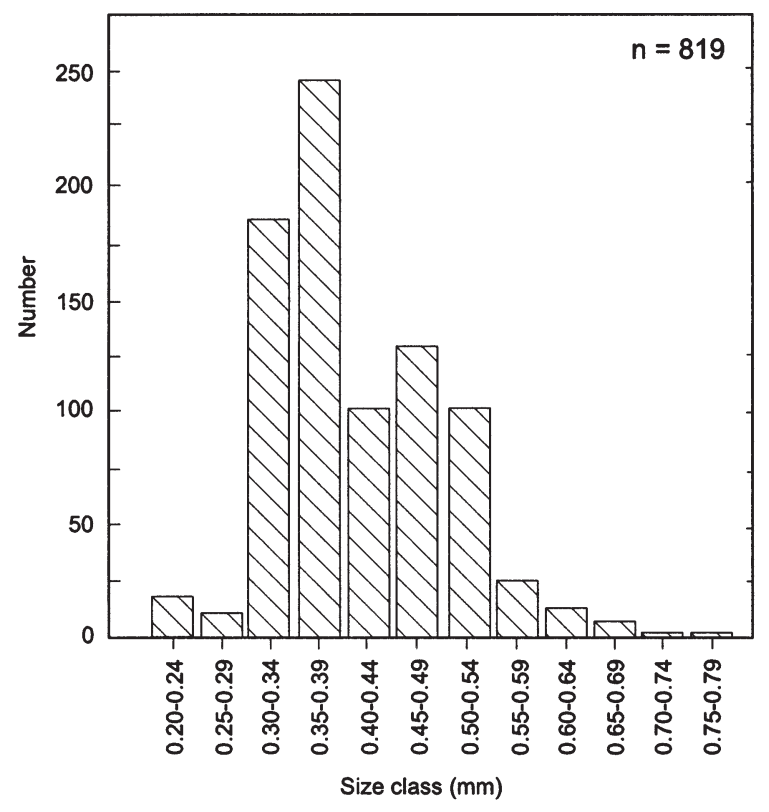

Fig. 2. Pooled size distribution of mussel larvae sampled in the plankton 


\section{RESULTS}

\section{Larval distribution}

Plankton samples collected 120 to $400 \mathrm{~m}$ offshore contained mytilid larvae (Rees 1950, Fuller \& Lutz 1989), almost certainly the most abundant local species Perna perna. Specimens were 0.2 to $0.8 \mathrm{~mm}$ in length (Fig. 2), indicating that some were late plantigrades (Bayne 1976, Seed \& Suchanek 1992), possibly undergoing secondary dispersal.

\section{Vertical stratification}

Larvae could be found at any depth in the shallow $(<20 \mathrm{~m})$ nearshore water column. Concentrations of larvae ranged from 0 to $140 \mathrm{~m}^{-3}$ and varied by up to 2 orders of magnitude among replicate samples. Larval concentrations were occasionally great near the surface or bottom, but there was no evidence for persistent vertical stratification. On 24 and 28 September 1990, 10 m plankton hauls caught more larvae $\mathrm{m}^{-3}$ than $1 \mathrm{~m}$ hauls (Mann-Whitney $U$-test, $\mathrm{p}<$ 0.001), indicating that larvae were not concentrated near the surface. On 18, but not 19 March 1991 larval abundance was significantly correlated with depth of water sampled $(\mathrm{p}<0.01)$.

On 9 of the 11 sampling occasions in October 1991, there was no significant difference between the observed vertical pattern of distribution and that expected with uniform vertical distribution (Kolmogorov-Smirnov tests, p > 0.05). On 2 occasions significant differences occurred in 1 of 3 replicates. In both cases the result was influenced by a single datum point and no such pattern was observed at replicate stations. This suggests that the observed pattern was due to vertical and horizontal patchiness rather than vertical migration.

Water flow was largely barotropic, moving in the same direction at different depths. Current flow ranged between 0.03 and $0.22 \mathrm{~m} \mathrm{~s}^{-1}$ and decreased with depth on only 2 out of 5 occasions. Normally, homogenous flow and the absence of vertical stratification suggest that larval behaviour has little influence on dispersal.

\section{Horizontal dispersal on station grids}

Larval densities were generally low with very patchy horizontal distribution. Relatively dense patches or

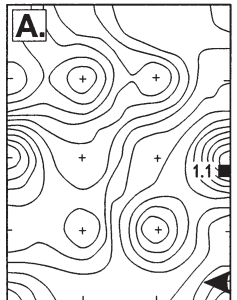

9:39h
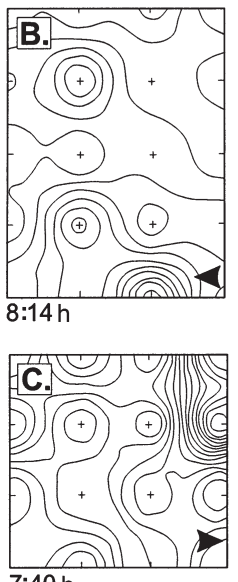

$7: 40 \mathrm{~h}$

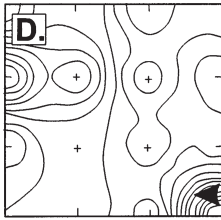

11:09 h

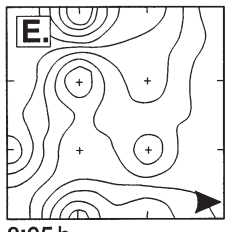

8:05 h

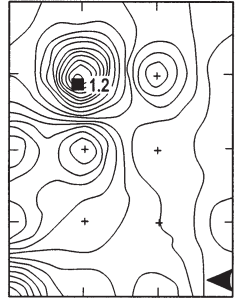

12:09h

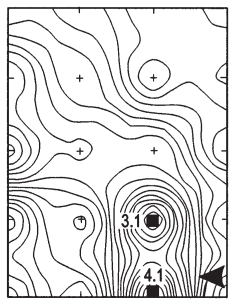

9:20h

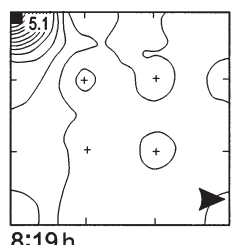

$8: 19 \mathrm{~h}$

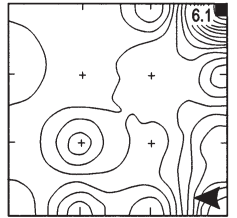

$11: 49 \mathrm{~h}$

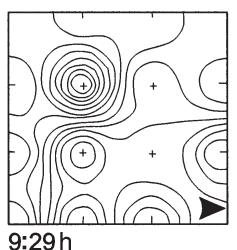

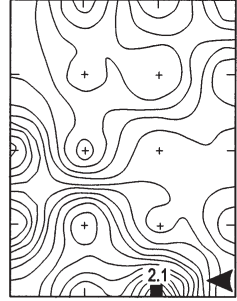

13:55 h

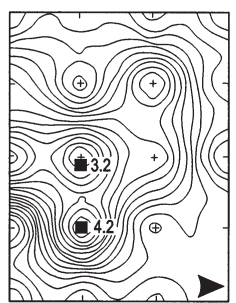

10:40h

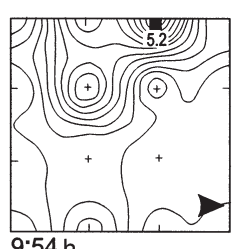

9:54 h

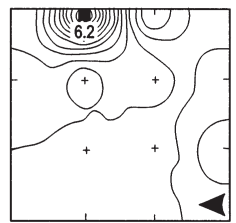

13:20h

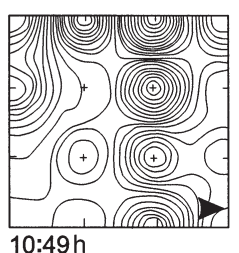

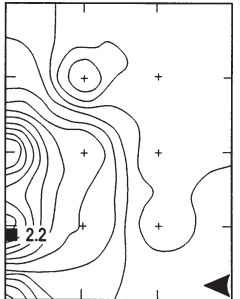

$16: 17 \mathrm{~h}$

Current direction

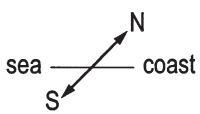

Fig 3. Contour maps of larval density on sampling grids. Rows A-E each represent a sampling session on one grid. A single grid was sampled 3 or 4 times during a session. Each panel represents 1 repeat. Numbers under each panel indicate the starting time of the repeat. The top of each panel represents the inshore edge of the grid. For A-D this was the breaker line, grid $\mathrm{E}$ was further offshore. Arrowheads indicate current direction. $\mathrm{A}=$ grid $1,24 / 9 / 90 ; \mathrm{B}=$ grid $1,28 / 9 / 90 ; \mathrm{C}=$ grid 1 , 18/3/91; D = grid 2,18/3/91; E = grid 3, 19/3/91. $1.1=$ cloud 1 , position $1 ; 1.2=$ cloud 1 , position 2 etc.

clouds of larvae were identified on the grids and the position of some clouds could be tracked through time from consecutive samples (Fig. 3). Clouds close to the surf zone tended to drift parallel to the shoreline while clouds farther offshore also moved onshore. It was not possible to track discrete clouds on grid 3 (Fig. 3E) which was farther offshore. Current speeds were significantly higher than inshore (ANOVA, $p<0.05$; followed by Tukey test) and clouds were probably 
Table 1. Direction and rate of movement of high concentration clouds of larvae across plankton grids. $\mathrm{x}=$ mean number of larvae

\begin{tabular}{|c|c|c|c|c|c|c|c|}
\hline \multirow[b]{2}{*}{ No. } & \multicolumn{6}{|c|}{ Longshore movement } & \multirow[b]{2}{*}{$\mathrm{x}$} \\
\hline & Date & Direct & $\begin{array}{l}\text { Dist. } \\
(\mathrm{m})\end{array}$ & $\begin{array}{l}\text { Time } \\
\text { (min) }\end{array}$ & $\begin{array}{c}\text { Dispe } \\
\left(\mathrm{m} \mathrm{s}^{-1}\right)\end{array}$ & $\begin{array}{l}\text { rsal rate } \\
\left(\mathrm{km} \mathrm{h}^{-1}\right)\end{array}$ & \\
\hline 1 & $24 / 9 / 90$ & SW & 600 & 113 & 0.08 & 0.30 & 18 \\
\hline 2 & & SW & 600 & 114 & 0.09 & 0.32 & 41 \\
\hline 3 & $28 / 9 / 90$ & SW & 300 & 48 & 0.10 & 0.36 & 90 \\
\hline 4 & & SW & 300 & 41 & 0.12 & 0.44 & 88 \\
\hline 5 & 18/3/91 am & $\mathrm{NE}$ & 600 & 115 & 0.09 & 0.31 & 42 \\
\hline 6 & $\mathrm{pm}$ & SW & 600 & 71 & 0.14 & 0.51 & 30 \\
\hline \multicolumn{2}{|c|}{ Mean $( \pm \mathrm{SD})$} & & & & & $\begin{array}{c}0.10 \\
( \pm 0.02)\end{array}$ & $\begin{array}{r}0.35 \\
( \pm 0.08)\end{array}$ \\
\hline
\end{tabular}

advected across the grid before being re-sampled. Six clouds were used to estimate rates of movement (Table 1) and are labelled on Fig. 3. The mean rate of cloud movement $(0.10, \mathrm{SD}$ $0.02 \mathrm{~m} \mathrm{~s}^{-1}$ ) fell within the range of current speeds recorded during sampling.

\section{Estimation of dispersal range}

Wind frequencies are given in Fig. 4. Two wind directions are especially important. NE winds are the only ones to produce westerly displacement and SW is the predominant wind direction. Estimated displacement was greatest for months when NE winds were less frequent. This generally occured in winter (May-August), but with considerable interannual variability. SW winds were especially frequent in spring and summer (OctoberFebruary) and blew for $30 \%$ of the entire 28 mo period. Calculations from wind data indicate total displacement of 118 to $229 \mathrm{~km}$ $\mathrm{mo}^{-1}$ (Fig. 5). Frequent changes in wind direction reduced net displacement to a mean of $121 \mathrm{~km}$ (range 54 to $180 \mathrm{~km} \mathrm{mo}^{-1}$ ) to the east. The calculated net dispersal range was eastwards in every month.

\section{Rate of spread of an invasive species}

Net dispersal of Mytilus galloprovincialis was primarily to the northeast, with limited spread to the southwest (Fig. 6). The density of M. galloprovincialis declined exponentially with distance eastwards from Port Elizabeth harbour in all $4 \mathrm{yr}$ sampled. There was a dramatic decrease in densities at distances $>4$ to $5 \mathrm{~km}$ from the parent population. After $4 \mathrm{yr}$ about $90 \%$ of all M. galloprovincialis were found within 12 to $20 \mathrm{~km}$ and none were found more than $166 \mathrm{~km}$ east of the harbour (Fig. 7). Maximum spread to the southwest was only $29 \mathrm{~km}$ and $M$. galloprovincialis densities at sites west of Port Elizabeth were extremely low, always $<200 \mathrm{~m}^{-2}$.

The rate of spread to the east declined steadily after the first year with no increase between 1991 and 1992. This was almost certainly due to the removal of the parent population when culturing was discontinued around this time. Populations established from
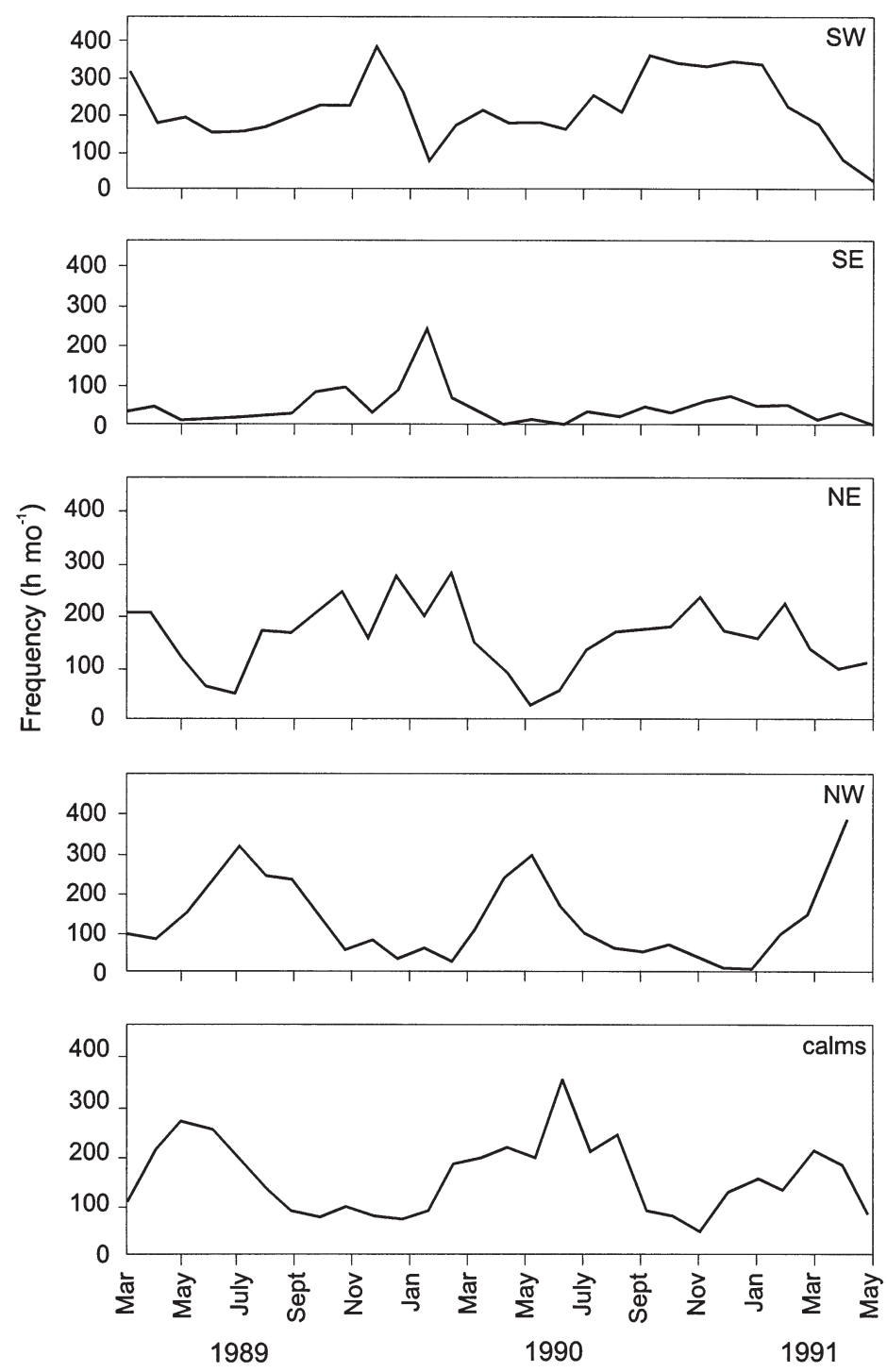

Fig. 4. Monthly frequencies $\left(\mathrm{h} \mathrm{mo}^{-1}\right.$ ) of winds blowing from the 4 principal wind directions at Port Elizabeth 1989 to 1991 


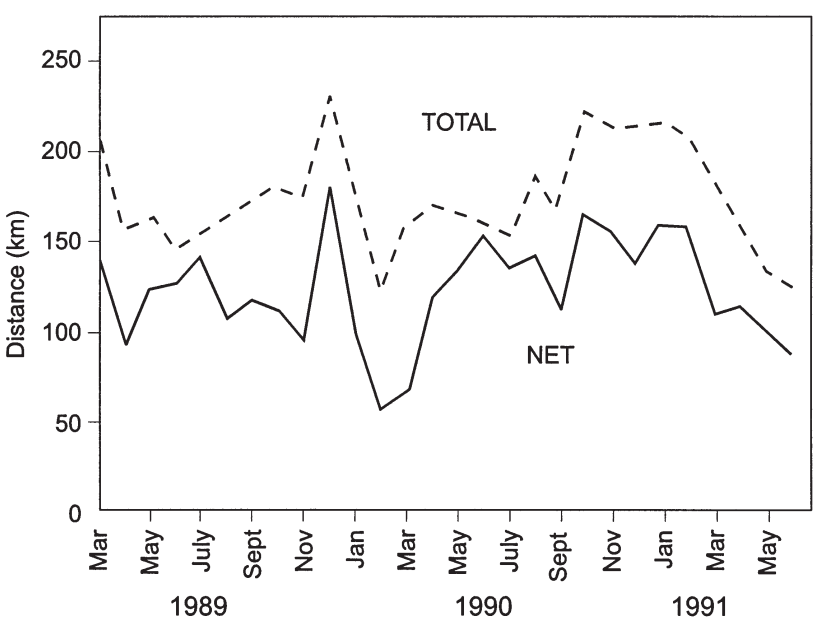

Fig. 5. Estimated monthly dispersal distances for passive particles moving with wind-driven currents in the vicinity of Kenton. Total displacement and net dispersal are shown. Net dispersal was eastwards in every month

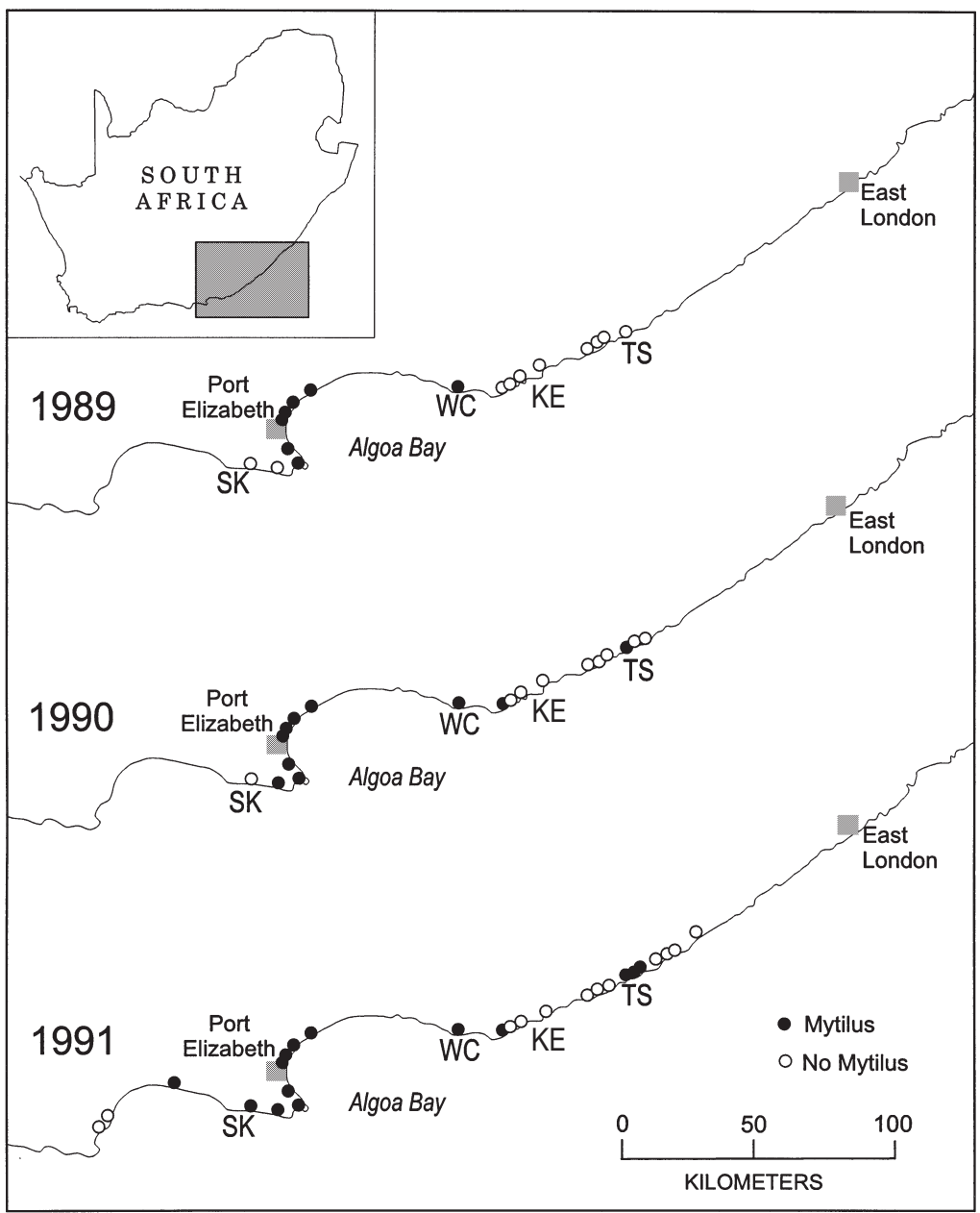

Fig. 6. Distribution of Mytilus galloprovincialis in the Algoa Bay region, 1989 to 1991. Areas between sampling sites are predominantly sandy beach. $\mathrm{SK}=$ Skoenmakerskop, WC $=$ Woody Cape, KE = Kenton, TS = Three Sisters the parent stock were still at very low densities (mostly below $500 \mathrm{~m}^{-2}$; Fig. 7) and formed a small proportion of total mussel numbers of 10 to $60000 \mathrm{~m}^{-2}$ (unpubl. data). The average annual increase in range over the entire 4 yr was $42 \mathrm{~km} \mathrm{yr}^{-1}$ to the east, and $19 \mathrm{~km} \mathrm{yr}^{-1}$ to the west (Table 2). By 1991, 3 yr after introduction, M. galloprovincialis had spread, albeit in very low numbers, along a total (east and west) of $223 \mathrm{~km}$ of coastline from Port Elizabeth.

\section{DISCUSSION}

Scales of larval dispersal are often estimated indirectly by linking the duration of planktonic life to genetic structure of populations. However, effective dispersal is not always correlated with the duration of larval life in the water column (McQuaid 1996), and genetic cohesion among populations can be achieved through the exchange of relatively few larvae. For a population to be ecologically open requires substantial larval exchange every generation.

Levin (1990) reviewed techniques used to track marine larvae. Short term, direct following of larvae is possible for animals such as ascidians, which have large larvae (e.g. Olson \& McPherson 1987, Davis \& Butler 1989, Young 1990, Bingham \& Young 1991). It can also be possible to track particularly dense aggregations of smaller larvae visually (e.g. Willis \& Oliver 1990), but this is rare. Larvae have also been marked using stains and trace element labels (see references in Levin 1990), but most studies of larval dispersal rely on indirect methods, including modelling water flow (Beukema \& de Vlas 1989, Sammarco \& Andrews 1989, Farrell et al. 1991, Gaines \& Bertness 1992, Pedrotti \& Fenaux 1992, Black 1993).

Mussel larvae are small (Rees 1950, Fuller \& Lutz 1989, Pulfrich 1997) and are in the water column for weeks (Seed 1969) so tracking or marking individuals is not feasible. Instead we used an average effect to follow relatively dense 3-dimensional clouds of larvae. Our results indicate that the larvae did not show strong diel vertical migration and on most occasions were spread evenly between the surface and the seabed. The water column where we sampled is shallow (ca $10 \mathrm{~m}$ ) and is strongly mixed 

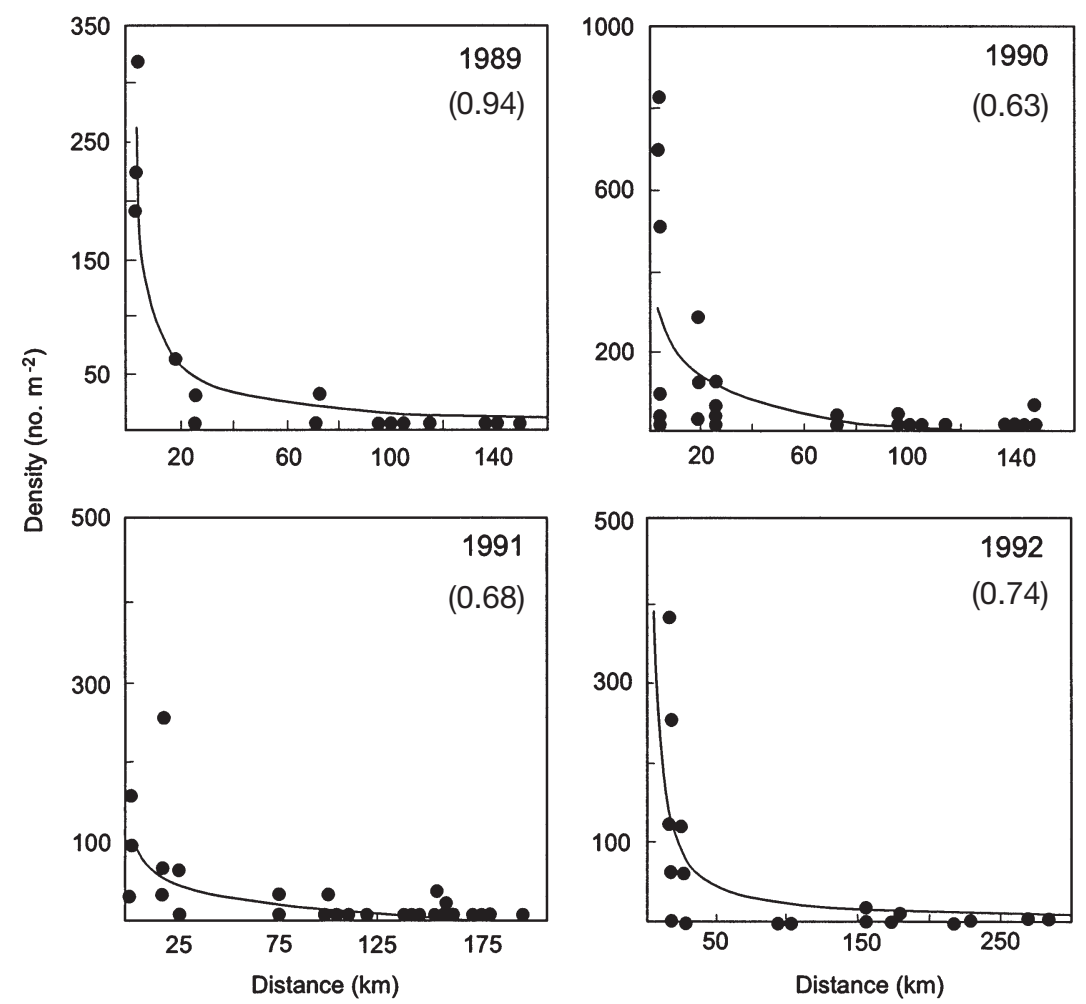

Fig. 7. Relationship between density of Mytilus galloprovincialis and distance east of Port Elizabeth in consecutive years. $r^{2}$ values in brackets

stage larvae (e.g. Sigurdsson et al. 1976, Lane et al. 1985). Nevertheless, the great majority of larvae were well below the size at which we would expect them to settle (Bayne 1964, Dare 1976, Sprung 1984, CaceresMartinez et al. 1993, Lasiak \& Barnard 1995). (3) We assume that we 'tracked' coherent, moving clouds across a sampling grid. Instead we could have identified 2 completely independent aggregations of larvae. Given the time scales on which grids were resampled, our assumption is reasonable. Aggregations of surf zone diatoms in this region form and disperse over periods of hours (Talbot et al. 1990). Also we cannot interpolate between our sampling stations so that distances can only be estimated between sample stations. (4) Our estimations can only apply to larvae which remain close to shore, but the larvae of intertidal species can be found kilometers offshore (Shanks 1983, 1986, Kendall et al. 1985, Roughgarden et al. 1988). On this coast, winds producing offshore water flow are rare (Schumann et al. 1991, Goschen \& Schumann 1995).

so that current direction is usually constant through the column, even though current velocity may decrease with depth. These 2 points imply that larvae are likely to be dispersed as passive particles transported by wind-driven surface currents.

If long-lived, planktonic larvae act as passive particles, then larval supply and recruitment should reflect local hydrographic conditions. This implies that (1) some sites will have predictably higher larval supply and (2) there may be directionality to larval dispersal if sites experience predominantly unidirectional flow, giving them upstream/downstream aspects (e.g. Sammarco \& Andrews 1989, Willis \& Oliver 1990, Black 1993). We compared predictions of dispersal based on wind data with the appearance of mussels which, in the first generation, could only have come from a single point source. There are difficulties with this approach. (1) We assumed larvae are in the water for $30 \mathrm{~d}$, based on previous data for Mytilus edulis (Chipperfield 1953, Seed 1969, Jorgensen 1981). In the laboratory at least, mussel larvae can delay metamorphosis for some time after becoming competent to metamorphose (Bayne 1965, Pechenik et al. 1990), thus potentially prolonging the period in the plankton considerably. (2) Some of the larvae were large. Our data on passive movement and the absence of vertical migration are thus partly for late
Larvae which were carried offshore could be advected by the Agulhas current which flows to the southwest at rates of 10 to $20 \mathrm{~km} \mathrm{~d}^{-1}$ (Lutjeharms 1981). The inshore thermal front of this current is normally 14 to $38 \mathrm{~km}$ offshore, but it can lie virtually on the coast at 0 to $1 \mathrm{~km}$ offshore (Goschen \& Schumann 1990). Farther west this current is deflected away from the African continent by the Agulhas Bank and undergoes a massive retroflection, moving hundreds of miles away from the mainland. There is no hope for the larvae of intertidal species which are caught up in this system. (5) We equated the appearance of new populations of Mytilus galloprovincialis with the range of dispersal of its larvae.

Table 2. Yearly increase in distributional range and mean rate of spread of Mytilus galloprovincialis to the east and west of Port Elizabeth harbour where it was first introduced in 1988

\begin{tabular}{|lcccc|}
\hline & 1988 & 1989 & 1990 & 1991 \\
\hline East & & & & \\
Distance increase $(\mathrm{km})$ & 0 & 97 & 56 & 13 \\
Mean rate $\left(\mathrm{km} \mathrm{yr}^{-1}\right)$ & & 97 & 77 & 55 \\
West & & & & \\
Distance increase $(\mathrm{km})$ & 0 & 16 & 12 & 29 \\
Mean rate $\left(\mathrm{km} \mathrm{yr}^{-1}\right)$ & & 16 & 14 & 19 \\
\hline
\end{tabular}


New populations represent the maximum effective spread of larvae in densities high enough to establish themselves among populations of the indigenous mussel Perna perna. i.e. we measured the spread of successful recruits, not necessarily larvae. However, we counted even a single individual as indicating M. galloprovincialis was present at a site and the vast majority of successful recruits appeared very close indeed to the original population (Fig. 7). Crisp (1958) also observed a rapid decrease in densities with increasing distance from the main population of the invasive barnacle Elminius modestus in Britain. Unless we assume increasing mortality of settlers with distance from the parent stock, this must imply that most larvae settled relatively close to their parents.

Despite these reservations, the results of our predictions from wind data were strongly validated by the actual spread of Mytilus galloprovincialis, in terms of both direction and distance. Clouds of larvae in the water drifted in the same direction and at the same speed as wind-driven surface currents. Estimating dispersal from wind data alone indicated a net displacement to the east on a scale of $10 \mathrm{~s}$ of $\mathrm{km} \mathrm{yr}^{-1}$. M. galloprovincialis showed exactly this pattern of dispersal. Larvae may be carried over maximum absolute distances of about $200 \mathrm{~km}$, but net displacement of most individuals will be only $10 \mathrm{~s}$ of $\mathrm{km}$ or less. It is presumably coincidence that Crisp (1958) found that Elminius modestus also advanced from a point source at 20 to $30 \mathrm{~km} \mathrm{yr}^{-1}$. Our findings concur with the mesoscale lack of recruitment in the Transkei region of the south coast of South Africa (Harris et al. 1998). This is an area approximately $250 \mathrm{~km}$ east of the study area where adult mussel populations have been dramatically reduced through human exploitation (Lasiak 1991, Dye et al. 1994). Lack of recruitment suggests that large numbers of larvae are not carried there from more distant populations.

There is evidence that at least some marine benthic populations are not particularly open. The mathematical model of Verdier-Bonnet et al. (1997) predicts that, under the most common wind conditions near Banyuls in France, populations of polychaets with larvae in the water for 4 wk would show little exchange between bays $<2 \mathrm{~km}$ apart. Todd et al. (1998), working with allozymes, found that populations of a nudibranch with pelagic lecithotrophic larvae were closed on surprisingly small spatial scales. Our results indicate the same for mussels with planktotrophic larvae on this coast. Bertness et al. (1992) suggested that pelagic larvae uncouple local reproductive output from local larval settlement. There is obviously a continuum between open and closed populations and terms such as 'local' need to be defined. If the majority of mussel larvae on this coast disperse on scales of $<10 \mathrm{~km}$ then these populations will be closed on scales of 1 to $10 \mathrm{~s}$ of $\mathrm{km}$, or perhaps 1 to $100 \mathrm{~km}$, which we term 'mesoscale'. However, if hydrography is so important, the link between reproductive output and recruitment, in other words the scales at which populations are closed, will vary geographically and perhaps also with time. Unexpectedly short dispersal ranges on the south coast of South Africa result specifically from the predominance of wind-driven currents coupled with frequent wind reversals. This supports Scheltema's (1986b) suggestion that, among the factors important in the horizontal transport of larvae, rates and direction of advection are usually related to wind forcing.

Acknowledgements. This project was funded by the Foundation for Research Development of South Africa and the Joint Research Committee of Rhodes University. We are grateful to both, and to Eckart Schumann for the loan of valuable equipment. We also thank Denis Crowcamp, Gurutze Calvo Ugarteburu and Winsome Wayman for help in the field, often under hazardous conditions. Rodrigo Bustamente helped with data analysis, and access to computer facilities was very kindly provided to TEP by the Zoology Department and the Percy Fitzpatrick Institute at the University of Cape Town.

\section{LITERATURE CITED}

Alexander SE, Roughgarden J (1996) Larval transport and population dynamics of intertidal barnacles: a coupled benthic/oceanic model. Ecol Monogr 66:259-275

Bayne BL (1964) Primary and secondary settlement in Mytilus edulis L. (Mollusca). J Anim Ecol 33:513-523

Bayne BL (1965) Growth and delay of metamorphosis of the larvae of Mytilus edulis L. Ophelia 2:1-47

Bayne BL (1976) The biology of mussel larvae. In: Bayne BL (ed) Marine mussels: their ecology and physiology. Cambridge University Press, Cambridge, p 81-120

Bertness MD, Gaines SD, Stephens EG, Yund PO (1992) Components of recruitment in populations of the acorn barnacle, Semibalanus balanoides (Linneus). J Exp Mar Biol Ecol 156:199-215

Beukema JJ, de Vlas J (1989) Tidal-current transport of thread-drifting postlarval juveniles of the bivalve Macoma balthica from the Wadden Sea to the North Sea. Mar Ecol Prog Ser 52:193-200

Bingham BL, Young CM (1991) Larval behaviour of the ascidian Ecteinascidia turbinata Herdman; an in situ experimental study of the effects of swimming on dispersal. J Exp Mar Biol Ecol 145:189-204

Black KP (1993) The relative importance of local retention and inter-reef dispersal of neutrally buoyant material on coral reefs. Coral Reefs 12:43-53

Booth DJ, Brosnan DM (1995) The role of recruitment dynamics in rocky shore and coral reef fish communities. Adv Ecol Res 26:309-385

Caceres-Martinez J, Robledo JAF, Figueras A (1993) Settlement of mussels Mytilus galloprovincialis on an exposed rocky shore in Ria de Vigo, NW Spain. Mar Ecol Prog Ser 93:195-198

Caley MJ, Carr MH, Hixon MA, Hughes TP, Jones GP, Menge BA (1996) Recruitment and the local dynamics of open marine populations. Annu Rev Ecol Syst 27:477-500 
Carricker MR (1951) Ecological observations on the distribution of oyster larvae in New Jersey estuaries. Ecol Monogr 21:19-38

Chipperfield PNJ (1953) Observations on the breeding and settlement of Mytilus edulis (L.) in British waters. J Mar Biol Assoc UK 32:449-476

Crisp DJ (1958) The spread of Elminius modestus Darwin in north-west Europe. J Mar Biol Assoc UK 37:483-520

Dare PJ (1976) Settlement, growth, and production of the mussel Mytilus edulis L., in Morecombe Bay, England. Fish Invest GB II 28:1-25

Davis AR, Butler AJ (1989) Direct observations of larval dispersal in the colonial ascidian Podoclavella moluccensis Sluiter: evidence for closed populations. J Exp Mar Biol Ecol 127:189-203

de Wolf P (1973) Ecological observations on the mechanisms of dispersal of barnacle larvae during planktonic life and settling. Neth J Sea Res 6:1-12

Dye AH, Schleyer MH, Lambert G, Lasiak TA (1994) Intertidal and sub-tidal filter-feeders in southern Africa. In: Siegfrid WR (ed) Ecological studies-rocky shores: exploitation in Chile and South Afrcia. Springer-Verlag, Berlin, p 57-73

Farrell TM, Bracher D, Roughgarden J (1991) Cross-shelf transport causes recruitment to intertidal populations in central California. Limnol Oceanogr 36:279-288

Fuller SC, Lutz RA (1989) Shell morphology of post-larval mytilids from the north-western Atlantic. J Mar Biol Assoc UK 69:181-218

Gaines SD, Bertness MD (1992) Dispersal of juveniles and variable recruitment in sessile marine species. Nature 360: 579-580

Goschen WS, Schumann EH (1990) Agulhas current variability and inshore structures off the Cape Province, South Africa. J Geophys Res 95:667-678

Goschen WS, Schumann EH (1995) Upwelling and the occurrence of cold water around Cape Receife, Algoa Bay, South Africa. S Afr J Mar Sci 16:57-67

Harris JM, Branch GM, Elliott BL, Currie B, Dye A, McQuaid CD, Tomalin B, Velasquez C (1998) Spatial and temporal variability in recruitment of intertidal mussels around the coast of southern Africa. S Afr J Zool 33:1-11

Heath MR, MacLachlan PM, Martin JHA (1987) Inshore circulation and transport of herring larvae off the north coast of Scotland. Mar Ecol Prog Ser 40:11-23

Hedgecock D (1986) Is gene flow from pelagic larval dispersal important in the adaptation and evolution of marine invertebrates? Bull Mar Sci 39:550-564

Hill AE (1990) Pelagic dispersal of Norway lobster Nephrops norvegicus larvae examined using an advection-diffusionmortality model. Mar Ecol Prog Ser 64:217-226

Hinckley S, Bailey KM, Picquelle SJ, Schumacher JD, Stabeno PJ (1991) Transport, distribution, and abundance of larval and juvenile Walleye Pollock (Theragra chalcogramma) in the western Gulf of Alaska. Can J Fish Aquat Sci 48:91-98

Hovel KA, Morgan SG (1997) Planktivory as a selective force for reproductive synchrony and larval migration. Mar Ecol Prog Ser 157:79-95

Jablonski D (1986) Larval ecology and macroevolution in marine invertebrates. Bull Mar Sci 39:565-587

Jablonski D, Lutz RA (1983) Larval ecology of marine benthic invertebrates: paleobiological implications. Biol Rev 58: 21-89

Jorgensen CB (1981) Mortality, growth, and grazing impact on a cohort of bivalve larvae Mytilus edulis L. Ophelia 20: 185-192
Kendall MA, Bowman RS, Williamson P, Lewis JR (1985) Annual variations in the recruitment of Semibalanus balanoides on the north Yorkshire coast 1969-1981. J Mar Biol Assoc UK 65:1009-1030

Lane DJW, Beaumont AR, Hunter JR (1985) Byssus drifting and the drifting threads of the young post-larval mussel Mytilus edulis. Mar Biol 84:301-308

Laprise R, Dodson JJ (1989) Ontogeny and importance of tidal vertical migrations in the retention of larval smelt Osmerus mordax in a well-mixed estuary. Mar Ecol Prog Ser 55:101-111

Lasiak TA (1991) The susceptibility and/or resilience of rocky littoral molluscs to stock depletion by the indigenous coastal people of Transkei, southern Africa. Biol Conserv $47: 245-257$

Lasiak TA, Barnard TCE (1995) The recruitment of the brown mussel Perna perna onto natural substrata: a refutation of the primary/secondary settlement hypothesis. Mar Ecol Prog Ser 120:147-153

Levin LA (1990) A review of methods for labelling and tracking marine invertebrate larvae. Ophelia 32:115-144

Lutjeharms JRE (1981) Features of the southern Agulhas Current circulation from remote sensing. S Afr J Sci 77: 231-236

McQuaid CD (1996) Biology of the gastropod family Littorinidae. I. Evolutionary aspects. Oceanogr Mar Biol Annu Rev 34:233-262

Olson RR, McPherson R (1987) Potential vs. realized larval dispersal: fish predation on larvae of the ascidian Lissoclinum patella (Gottschaldt). J Exp Mar Biol Ecol 110: $245-256$

Palmer MA, Allan JD, Butman CA (1996) Dispersal as a regional process affecting the local dynamics of marine and stream benthic invertebrates. Trends Ecol Evol 11: 322-326

Pechenik JA, Eyster LS, Widdows J, Bayne BL (1990) The influence of food concentration and temperature on growth and morphological differentiation of blue mussel Mytilus edulis L. larvae. J Exp Mar Biol Ecol 136:47-64

Pedrotti AM, Fenaux L (1992) Dispersal of echinoderm larvae in a geographical area marked by upwelling (Ligurian Sea, NW Mediterranean). Mar Ecol Prog Ser 86:217-227

Perron FE, Kohn AJ (1985) Larval dispersal and geographic distribution in coral reef gastropods of the genus Conus. Proceedings of the 5th Interational Coral Reef Congr 95-100

Pineda J (1991) Predictable upwelling and the shoreward transport of planktonic larvae by internal tidal bores. Science 253:548-551

Possingham HP, Roughgarden J (1990) Spatial population dynamics of a marine organism with a complex life cycle. Ecology 71:973-985

Pulfrich A (1997) Seasonal variation in the occurrence of planktic bivalve larvae in the Schleswig-Holstein Wadden Sea. Helgol Meeresunters 51:23-39

Rees CB (1950) The identification and classification of lamellibranch larvae. Hull Bull Mar Ecol 3:73-104

Roberts M (1989) Dispersion of a buoyant effluent discharged into the nearshore waters of Algoa Bay. MSc thesis, University of Port Elizabeth

Roughgarden J, Iwasa Y, Baxter C (1985) Demographic theory for an open marine population with space-limited recruitment. Ecology 66:54-67

Roughgarden J, Gaines S, Possingham H (1988) Recruitment dynamics in complex life cycles. Science 241:1460-1466

Sammarco PW, Andrews JC, (1989) The Helix experiment: differential localized dispersal and recruitment patterns in 
Great Barrier Reef corals. Limnol Oceanogr 34:896-912

Scheltema RS (1966) Evidence for trans-Atlantic transport of gastropod larvae belonging to the genus Cymatium. Deep-Sea Res 13:83-95

Scheltema RS (1968) Dispersal of larvae by equatorial ocean currents and its importance to the zoogeography of shoalwater tropical species. Nature 217:1159-1162

Scheltema RS (1971) Larval dispersal as a means of genetic exchange between geographically separated populations of shallow-water benthic marine gastropods. Biol Bull 140: 284-322

Scheltema RS (1986a) Long-distance dispersal by planktonic larvae of shoal-water benthic invertebrates among central Pacific islands. Bull Mar Sci 39:241-256

Scheltema RS (1986b) On dispersal and planktonic larvae of benthic invertebrates: an eclectic overview and summary of problems. Bull Mar Sci 39:290-322

Scheltema RS, Williams IP (1983) Long-distance dispersal of planktonic larvae and the biogeography and evolution of some Polynesian and Western Pacific mollusks. Bull Mar Sci 33:545-565

Schumann EH, Illenberger WK, Goschen WS (1991) Surface winds over Algoa Bay, South Africa. S Afr J Sci 87: 202-207

Seed R (1969) The ecology of Mytilus edulis L. (Lamellibranchiata) on exposed rocky shores. II. Growth and mortality. Oecologia 3:317-350

Seed R, Suchanek TH (1992) Population and community ecology of Mytilus. In: Gosling E (ed) The mussel Mytilus: ecology, physiology, genetics and culture. Elsevier, Amsterdam, p 87-157

Shanks AL (1983) Surface slicks associated with tidally forced internal waves may transport pelagic larvae of benthic invertebrates and fishes shoreward. Mar Ecol Prog Ser 13: 311-315

Shanks AL (1986) Tidal periodicity in the daily settlement of intertidal barnacle larvae and a hypothesized mechanism for the cross-shelf transport of cyprids. Biol Bull 170:429-440

Editorial responsibility: Roger Hughes (Contributing Editor), Bangor, Wales, UK
Sigurdsson JB, Titman CW, Davies PA (1976) The dispersal of young post-larval bivalve molluscs by byssus threads. Nature 262:386-387

Sprung M (1984) Physiological energetics of mussel larvae (Mytilus edulis). I. Shell growth and biomass. Mar Ecol Prog Ser 17:283-293

Stoner DS (1990) Recruitment of a tropical colonial ascidian: relative importance of pre-settlement vs post-settlement processes. Ecology 71:1682-1690

Strathmann RR (1990) Why life histories evolve differently in the sea. Am Zool 30:197-207

Talbot MMB, Bate GC, Campbell EE (1990) A review of the ecology of surf-zone diatoms, with special reference to Anaulis australis. Oceanogr Mar Biol Annu Rev 28: $155-175$

Todd CD, Lambert WJ, Thorpe JP (1998) The genetic structure of intertidal populations of two species of nudibranch molluscs with planktonic and pelagic lecithotrophic larval stages: are pelagic larvae 'for' dispersal? J Exp Mar Biol Ecol 228:1-28

Verdier-Bonnet C, Carlotti F, Rey C, Bhaud M (1997) A model of larval dispersion coupling wind-driven currents and vertical larval behaviour: application to the recruitment of the annelid Owenia fusiformis in Banyuls Bay, France. Mar Ecol Prog Ser 160:217-231

Willis BL, Oliver JK (1990) Direct tracing of coral larvae: implications for dispersal studies of planktonic larvae in topographically complex environments. Ophelia 32: 145-162

Wood L, Hargis WJ Jr (1971) Transport of bivalve larvae in a tidal estuary. In: Crisp DJ (ed) Proceedings of the 4th European Marine Biological Symposium, Cambridge University Press, London, p 21-44

Young CM (1990) Direct observations of field swimming behaviour in larvae of the colonial ascidian Ecteinascidia turbinata. Bull Mar Sci 39:279-289

Zar J (1984) Biostatistical analysis, 2nd edn. Prentice Hall, Englewood Cliffs, NJ

Submitted: May 19, 1998; Accepted: February 1, 2000 Proofs received from author(s): July 4, 2000 